\title{
Arteriovenous fistula takedown in hemodialysis patients: our experience of 26 cases
}

\author{
Abhishek Shrinivas Joshi, Deepi Pradip Agrawal \\ Seth G.S. Medical College and K.E.M. Hospital, Mumbai, Maharashtra, India
}

Kardiochir Torakochir Pol 2020; 17 (3): 132-136

\begin{abstract}
Introduction: Creation of arteriovenous fistulas (AVF) for providing vascular access in patients dependent on hemodialysis is a very frequent type of surgery. One of the common complications of such a fistula is the formation of an aneurysm or a pseudoaneurysm and the risk of impending rupture. These are a few of the reasons why such surgically created AVF have to be taken down surgically. Some of these may be taken down for cosmetic reasons electively while some present in an emergency due to rupture of the aneurysm itself.

Aim: This is a retrospective study of 26 patients who underwent AVF takedown at our center over a period of 4 years.

Material and methods: We intended to study the patient profile, the surgery that they underwent and the post-operative course of these patients.

Results: We found that aneurysm formation was the most common reason for a takedown, although we did see a good percentage of patients who presented to us with a ruptured AVF aneurysm. Our procedure was a ligation of the aneurysm with resection of the aneurysmal segment and maintaining arterial continuity. No attempt to preserve the fistula was made in any of these cases.

Conclusions: This article gives a brief overview of our experience in AVF takedown.
\end{abstract}

Key words: fistula, aneurysm, rupture, takedown.

\section{Introduction}

Hemodialysis remains the most widely practiced therapy for patients with chronic renal failure due to the small number of available kidney donors [1]. To gain vascular access for hemodialysis, many of these patients undergo creation of an arteriovenous fistula (AVF). This procedure does have its own complications which add to the existing burden faced by these patients. Such surgically created fistulas can grow into aneurysms. Repeated punctures for vascular access can lead to pseudoaneurysm formation in such fistulas. These aneurysms and pseudoaneurysms are at risk

\section{Streszczenie}

Wprowadzenie: Wytworzenie przetoki tętniczo-żylnej (AVF) w celu uzyskania dostępu naczyniowego do hemodializy jest powszechnie wykonywanym zabiegiem. Jednym z częstych powikłań przetoki jest powstanie tętniaka lub tętniaka rzekomego, a w związku z tym ryzyko jego pęknięcia. Z tego powodu chirurgicznie wytworzona AVF wymaga usunięcia chirurgicznego. Niektóre przetoki są usuwane w trybie planowym ze względów kosmetycznych, a usuwanie innych odbywa się ze wskazań nagłych z powodu pęknięcia tętniaka.

Cel pracy: Przeprowadzono retrospektywne badanie 26 pacjentów, u których wykonano zabieg usunięcia AVF w naszym ośrodku w czasie 4 lat.

Materiat i metody: Analizie poddano profil pacjentów, rodzaj wykonanego zabiegu oraz przebieg pooperacyjny.

Wyniki: Powstanie tętniaka było najczęstszą przyczyną zabiegu, chociaż u znacznego odsetka pacjentów powodem podjęcia interwencji było pęknięcie tętniaka powstałego w AVF. Zabieg chirurgiczny polegał na podwiązaniu tętniaka oraz wycięciu odpowiedniego odcinka bez naruszenia ciągłości tętnicy. W żadnym z analizowanych przypadków nie podjęto próby zachowania przetoki.

Wnioski: W artykule przedstawiono krótkie omówienie doświadczeń własnych w usuwaniu AVF.

Słowa kluczowe: przetoka, tętniak, pęknięcie, usunięcie.

of impending rupture when they enlarge too much [2]. Rupture and eventual bleeding is also common in such patients and such patients usually present as a surgical emergency. Therefore, takedown of a surgically created AVF becomes a procedure as important as the creation of the AVF. We present our experience with surgical takedown of such AVF.

\section{Aim}

Our aim was to study the patient profile, reasons for AVF excision, the surgery that they underwent and the post-operative course of these patients.

Address for correspondence: Abhishek Shrinivas Joshi, Seth G.S. Medical College and K.E.M. Hospital, Mumbai, Maharashtra, India, phone: +91 9820326126, e-mail: drabhisheksjoshi@gmail.com

Received: 26.04.2020, accepted: 7.07.2020. 


\section{Material and methods}

We analyzed 26 patients who underwent AVF takedown at our center over a period of 4 years between January 2016 and January 2020. We assessed the profile of the patients with respect to their age, sex, time interval between fistula creation and excision. We could not do a pre-operative ultrasonography in all patients as some of them presented in an emergency. These patients underwent surgery and were analyzed with various parameters related to surgery such as duration of surgery, postoperative complications, and discharge status.

\section{Surgery}

Surgery was performed under local anesthesia with sedation or under axillary block. Patients were taken in the operation theatre after confirming at least one pint of cross matched whole blood. We operated on all patients with a cardiac anesthetist backup. These patients underwent surgery under local anesthesia with sedation or under axillary block. The agent used at our center for sedation was a fentanyl bolus $(0.05-2 \mu \mathrm{g} / \mathrm{kg})$ with dexmedetomidine infusion $(0.2-0.7 \mu \mathrm{g} / \mathrm{kg} / \mathrm{h})$ and for local anesthesia, we used a combination of bupivacaine diluted to $0.125-0.25 \%$ $(2-3 \mathrm{~m} / \mathrm{kg})$ and lignocaine $1 \%(5 \mathrm{mg} / \mathrm{kg})$. The same local anesthetic agents were used to administer axillary block as well. Our surgical approach was similar for all cases. For proximal or brachiocephalic fistulas, we gained control over the brachial artery by looping it through a separate incision in the mid arm. Once that control was achieved, we incised at the fistula site. For distal or radiocephalic fistulas, we took control at the elbow over the brachial artery by looping it. Then we proceeded to the dissection of the fistula. In case we encountered any bleeding during dissection, we would tighten the loop or clamp the proximal artery with a DeBakey clamp. Once the fistula site was well delineated, we would clamp the artery proximally and distally, ligate the aneurysm and under-run the aneurysm at the anastomotic site. The remnant of the aneurysmal sac would be excised and sent for histopathology (Figures 1, 2). In cases where simple under running was not possible, after excision of the aneurysm, we had to do an end-to-end anastomosis of the artery or a venous graft interposition to maintain arterial continuity and ensure distal pulsations in the artery. Any areas of skin breakdown or thinning of the skin were also excised. Hemostasis was achieved and skin was sutured with interrupted non-absorbable sutures. For patients who presented to us with bleeding, we tied a tourniquet around the proximal arm as the first step and the remainder of the steps were the same.

\section{Results}

A total of 26 patients underwent takedown of their AVF during this 4-year period. There were 15 male and 11 female patients ranging in age from 14 to 75 years with a mean age of $36.7 \pm 15.2$ years. Patients were referred to our department by the casualty department in case of a bleeding fistula or by the nephrology department for other causes. Four out of 26 patients had the fistula on their right arm as compared to 22 out of 26 who had a fistula on their left arm. Twenty-one out of 26 were brachiocephalic fistulas made at the elbow while the remaining 5 were radial cephalic fistulas. We found that these fistulas had been created around 21 to 51 months ago with a mean of $38.4 \pm 8.4$ months. In those fistulas which presented as aneurysms or pseudoaneurysms with a risk of impending rupture, these fistulas were created around 21 to 51 months before with a mean of $40 \pm 9.4$ months. In the case of patients with fistulas who presented to us with an aneurysm rupture they had been created around 41 to 47 months ago with a mean of $43 \pm 2.4$ months (Table I). Half of the patients underwent AVF excision due to presence of an aneurysm or a pseudo aneurysm with a risk of impending rupture.

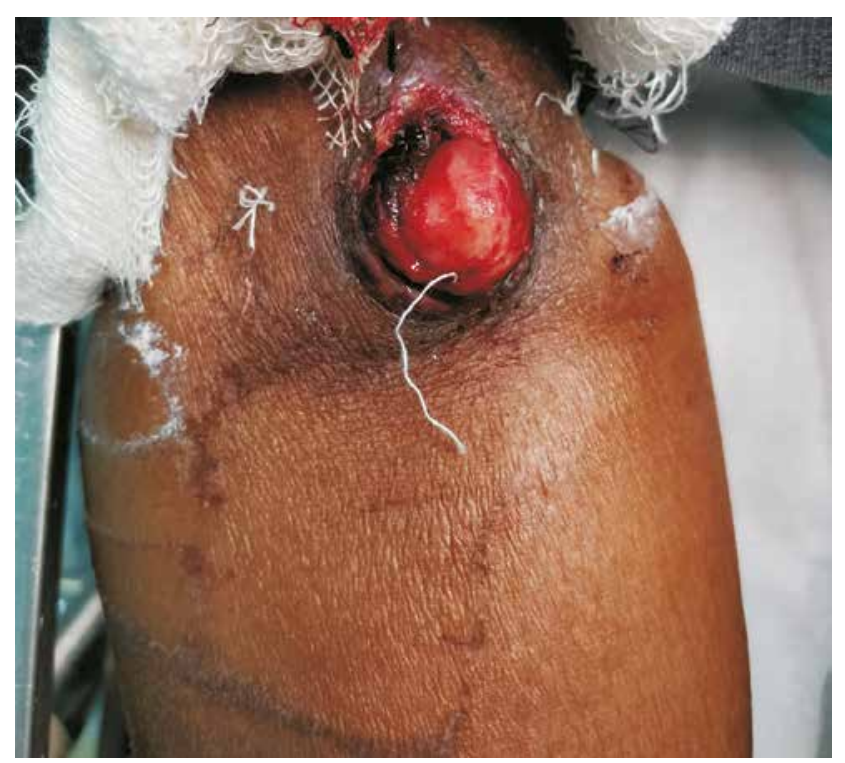

Figure 1. Aneurysmal fistula

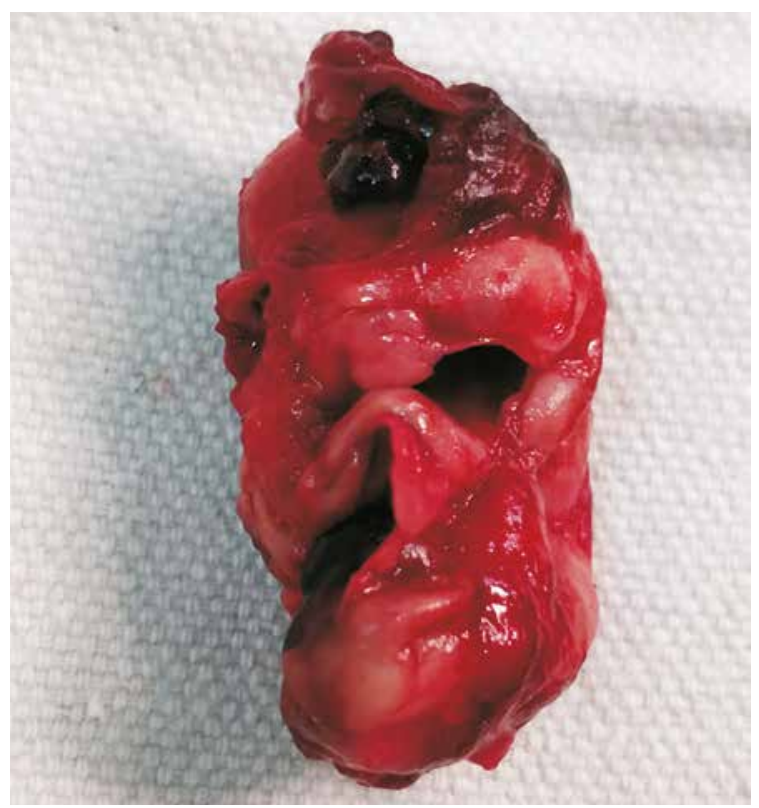

Figure 2. Excised aneurysm 
Table I. Reasons for arteriovenous fistulas takedown with fistula age

\begin{tabular}{|c|c|c|}
\hline Reason for AVF takedown & Number & $\begin{array}{l}\text { Age of fistula } \\
\text { [months] }\end{array}$ \\
\hline Aneurysm/pseudo-aneurysm & $13 / 26(50 \%)$ & $40 \pm 9.4$ \\
\hline Aneurysm rupture & $6 / 26(23 \%)$ & $43 \pm 2.4$ \\
\hline After renal transplant & $4 / 26(15.3 \%)$ & $46.25 \pm 7.1$ \\
\hline Ipsilateral gigantism & $2 / 26(7.6 \%)$ & $39 \pm 5.6$ \\
\hline $\begin{array}{l}\text { Ipsilateral subclavian } \\
\text { vein obstruction }\end{array}$ & $1 / 26(3.8 \%)$ & 31 \\
\hline Total & $26 / 26$ & $38.4 \pm 8.4$ \\
\hline
\end{tabular}

The next most common reason was rupture of the aneurysm in 6 patients. Four patients were sent to us by our nephrology department as they had undergone a successful renal transplant. The other reasons for surgery were gigantism in the affected limb and ipsilateral subclavian vein obstruction. Twenty-four out of 26 patients underwent the procedure under axillary block while the remaining 2 were operated on under local anesthesia and minimal sedation. Mean operative time was $66.1 \pm 14.5 \mathrm{~min}$. Mean duration of stay in the hospital was 2.8 days with a maximum stay of 6 days. Three of our patients had wound infection as a complication; otherwise there were no other complications. 5 out of the 26 patients that we operated on were positive for hepatitis $B$, hepatitis $C$ or HIV. All patients had good distal pulsations in the postoperative period and were successfully discharged. We did ligation of the fistula and simple under running of the aneurysmal site in 18 out of 26 patients. Four patients underwent an end-to-end arterial anastomosis and 4 underwent a venous interposition grafting to maintain arterial continuity. All these patients underwent a pre-operative central line insertion for dialysis and underwent 1 or 2 cycles of dialysis during their hospital stay. They were called for follow-up and underwent creation of fistula at a later date. On follow up (1 month - 4 years), all patients were found to have good distal pulsations without any recurrence of an aneurysm.

\section{Discussion}

Renal transplantation is the best treatment for patients with chronic renal failure; however, hemodialysis is the most common treatment. In order to aid in vascular access, these patients undergo creation of an AVF usually at the distal wrist, i.e. the radiocephalic fistula, or at the elbow, i.e. the brachiocephalic fistula. Such fistulas are associated with their own complications such as aneurysm formation or pseudoaneurysm formation. Usually the venous side of the fistula becomes aneurysmal. The definitive cause of such aneurysms is unknown. A true aneurysm is a vascular dilatation containing all its wall layers intact. Conversely, a pseudoaneurysm is a dilatation with disruption of one or more layers of its wall. A pseudoaneurysm wall typically contains neointima and fibrous tissue and sometimes is lined with thrombus. Repeated punctures for vascular access can lead to thinning of the walls of such aneurysms and may lead to their rupture $[3,4]$. Such ruptured aneurysms are surgical emergencies. The reasons mentioned above are the common reasons for excision of such AVF. The other subset is patients who have undergone a successful renal transplant. In patients who had a successful renal transplantation, the decision to keep a patent AVF remains controversial. If the renal graft function deteriorates, creation of a new vascular access will be required if the original functioning AVF has been excised. However, in a patient with a well-functioning renal graft, the risk of keeping an AVF appears to outweigh the benefits. The appearance of unsightly distended veins is also a reason why the patient may want to get his AVF excised. The ipsilateral limb may become gigantic due to the fistula. In cases of subclavian vein obstruction on the same side, the increased blood flow with a subsequent venous obstruction can pose a problem. Color Doppler ultrasonography is helpful in confirming the diagnosis and choosing the appropriate surgical approach. Other tools that may be helpful in the diagnosis of aneurysms are magnetic resonance angiography and/or fistulography with concomitant upper limb angiography. Treatment modalities include manual ligation and compression under ultra-sonographic guidance, endovascular graft implantation, embolization, thrombin injection under ultra-sonographic guidance and surgical reconstruction. Endovascular procedures are intended to maintain patency and function of the existing access while excluding the aneurysm or pseudoaneurysm from the circulation. Traditionally, the treatment of focal venous aneurysms has involved resection of the aneurysmal dilatation with interposition bypass grafting using a synthetic graft. Resection with reestablishment of venous continuity with end-to-end anastomosis has also been performed. Karabay et al. [5] described excision of the aneurysm and the communicating veins with restoration of the arterial patency. Moini et al. [6] described a new technique. After ligation of the AVF, two ends of the aneurysm were cut and released for drainage of the aneurysm. Then the incision was closed in layers. However, these two procedures leave the patient without a functional fistula. Therefore, various conservative techniques have been proposed for the correction of a venous aneurysm. Lo and Tan [7] and Okten et al. [8] suggested simple plication of the vessel using a running suture. Pierce et al. [9] proposed the use of a surgical stapler to reshape the venous aneurysm. At our center, we have excised the venous aneurysms and aimed at maintaining arterial continuity. Patients who come to us for fistula creation and dialysis are from a poor socioeconomic background and often do not follow up regularly. We have also encountered patients who present with rupture of the fistula and severe bleeding. Due to logistical difficulties, such patients do not reach the hospital on time. Hence, we have formulated such a policy to not try and conserve the fistula. However, all patients get a new access for immediate hemodialysis and are appointed for a new fistula creation on the other arm at the earliest.

Patients who presented to us with aneurysms or pseudo-aneurysms had a mean age of $40 \pm 9.4$ months. In a study carried out by Pasklinsky et al. [10], they reported 
47 months' patency of AVF from creation to treatment. Georgiadis et al. [11] reported the primary survival time of the first AVF to be $20.4 \pm 2.6$ months. Hence the time interval between AVF creation and aneurysmal dilatation is variable. We observed a mean of $43 \pm 2.4$ months' age for AVFs which presented to us with rupture/bleeding. The difference of these mean ages is just around 3 months. This means once the fistula has undergone aneurysmal dilatation, it is prone to rupture or bleeding. Hence patients with aneurysmal AVFs need to undergo AVF takedown as early as possible or need to be monitored very closely. At our center, patients generally come from far off places, so it is virtually impossible to keep a very close follow-up of these patients. As a result of this, we have formulated a policy of total excision of the AVF rather than preservation as described in a few articles.

The average size of the aneurismal fistulas in our study was around $4 \mathrm{~cm}(3 \mathrm{~cm}$ to $7 \mathrm{~cm})$. However, patients were generally referred to us when skin changes such as thinning of the skin overlying the fistula had started irrespective of the size of the fistula. Due to poor general medical knowledge in our country, a few patients tend to present even later when such fistulas start to ulcerate. In our opinion, nephrologists need to watch for such changes so that patients get referred on time and do not present with devastating complications such as rupture.

The staff at our hospital employ the button hole technique for cannulation, but the same cannot be applied for all patients in this study as many of them had their AVFs created at some other center. There is literature which suggests that the button hole technique has less chance of development of aneurysms as compared to the rope ladder technique [12-14].

The needle size used at our center is $16 \mathrm{G}$ or $17 \mathrm{G}$. Needles of size $14 \mathrm{G}$ or $15 \mathrm{G}$ are used in foreign countries. We have thus found that aneurysm formation can occur even with needles of smaller size.

We found that axillary block is very effective for such surgery and can achieve good post-operative pain relief as well. For fistulas at the wrist, local anesthesia with minimal sedation can also be used. We found brachio-cephalic fistulas very common as compared to radial cephalic to undergo aneurysm formation and rupture. The propensity of fistulas in the antecubital area to develop complications such as aneurysms must be borne in mind when choosing this anatomical site for the formation of AVFs for hemodialysis. At our center, we generally create a fistula distally, i.e. radial cephalic fistula. In case of failure of the fistula, we progress proximally and finally create an AVF at the elbow. We encountered left arm fistula more often as compared to right. At our center, we prefer the left side as the first site for the AVF so as to keep the right hand free (which is dominant in most individuals).

Surgical takedown of such fistulas is a simple procedure and our surgical times have been just around an hour. Achieving proximal control before dissecting the aneurysm or fistula site can keep blood loss to a minimum. After excision of the problematic segments, arterial continuity can be maintained by either an end-to-end anastomosis or via a venous interposition or a PTFE graft interposition. We have achieved arterial continuity by mainly end-to-end anastomosis and by vein interposition. We achieved good results postoperatively with our methods and had no vascular problems at all.

In our hospital, we schedule the patient for surgery in consultation with the nephrology department. Usually in the case of a non-ruptured aneurysm, the patient undergoes hemodialysis and then undergoes fistula takedown. Patients who presented with rupture underwent fistula takedown first followed by a cycle of hemodialysis.

The rate of wound infection in our series was $11.5 \%$ $(3 / 26)$. These patients were discharged late as compared to the other patients in our series. Renal impairment is known to create problems in wound healing and thus was evident in our series [15]. Treatment of such wound infection is relatively simple owing to the small incision. These patients also responded well to simple wound drainage and debridement. Although wound healing is a concern, such infected wounds generally do not create many problems in the postoperative period. Apart from wound infection, we encountered no other complications.

We observed that $19 \%(5 / 26)$ of the patients were positive for HBV, HCV or for HIV. It is important to note that these are common in patients undergoing hemodialysis and hence use of personal protective equipment is a must when doing any kind of fistula takedown [16].

\section{Conclusions}

Surgical takedown of a hemodialysis access AVF is a simple surgical procedure associated with very few complications. The chief reasons for such a procedure are aneurysm formation, rupture and bleeding or after a successful renal transplant. Although methods for preservation of the fistula are mentioned, these patients need a good surgical follow-up to look for further aneurysm formation. Our method of takedown is a sure-shot method and has good results at early and late follow-up. It is important to screen patients for serology before taking them for surgery and use personal protective equipment during surgical takedown of arteriovenous fistulas.

\section{Disclosure}

The authors report no conflict of interest.

\section{References}

1. Agarwal SK, Srivastava RK. Chronic kidney disease in India: challenges and solutions. Nephron Clin Pract 2009; 111: c197-c203.

2. Wang A, Silberzweig JE. Brachial artery pseudoaneurysms caused by inadvertent hemodialysis access needle punctures. Am J Kidney Dis 2009; 53 351-354.

3. Ekim H, Odabasi D, Basel H, Aydin C. Management of giant venous aneurysms secondary to arteriovenous fistula in hemodialysis patients. Pak J Med Sci 2011; 27: 1028-1032.

4. Schatz IJ, Fine G. Venous aneurysms. N Engl J Med 1962; 266: 1310-1312.

5. Karabay O, Yetkin U, Silistreli E, et al. Surgical management of giant aneu rysms complicating arteriovenous fistulae. J Int Med Res 2004; 32: 214-217. 
6. Moini M, Rasouli MR, Seyedmahmoodian H. Releasing versus ligation of 2 tails of large venous aneurysms secondary to dialysis arteriovenous fistulas. Vasc Endovasc Surg 2009; 43: 222.

7. Lo HY, Tan SG. Arteriovenous fistula aneurysm-plicate, not ligate. Ann Acad Med Singapore 2007; 36: 851-853.

8. Okten CC, Gunday M, Demirbas M. Surgical treatment of venous aneurysms developing in arteriovenous fistulae in hemodialysis patients. Turk J Thorac Cardiovasc Surg 2010; 18: 196-199.

9. Pierce GE, Thomas JH, Fenton JR. Novel repair of venous aneurysms secondary to arteriovenous dialysis fistulae. Vasc Endovasc Surg 2007; 41: 55-60.

10. Pasklinsky G, Meisner RJ, Labropoulos N, et al. Management of true aneurysms of hemodialysis access fistulas. J Vasc Surg 2011; 53: 1291-1297.

11. Georgiadis G, Lazarides M, Panagoutsos S, et al. Surgical revision of complicated false and true vascular accessrelated aneurysms. J Vasc Surg 2008; 47: 1284-1291.
12. Mudoni A, Cornacchiari M, Gallieni M, et al. Aneurysms and pseudoaneurysms in dialysis access. Clin Kidney J 2015; 8: 363-367.

13. Wong B, Muneer M, Wiebe N, et al. Buttonhole versus rope-ladder cannulation of arteriovenous fistulas for hemodialysis: a systematic review. Am J Kidney Dis 2014; 64: 918-936.

14. van Loon MM, Goovaerts T, Kessels AG, et al. Buttonhole needling of haemodialysis arteriovenous fistulae results in less complications and interventions compared to the rope-ladder technique. Nephrol Dial Transplant 2010; 25: 225-230.

15. Maroz N, Simman R. Wound healing in patients with impaired kidney function. J Am Coll Clin Wound Spec 2014; 5: 2-7.

16. Kamal IMA, Mahdi BM. Seroprevalence occurrence of viral hepatitis and HIV among hemodialysis patients. Ann Med Surg 2018; 29: 1-4. 